\title{
Repellency of Five Indigenous Plant oils against Red Flour Beetle, Triboliumcastaneum
}

\author{
Syedaazra Tariq ${ }^{1}$, M. F. Khan ${ }^{2}$, Hinazafer ${ }^{1 *}$, Waseem Abassi ${ }^{3}$ \\ ${ }^{1}$ Vertebrate Pest Control Institute, Southern-zone Agricultural Research Centre, Pakistan Agricultural \\ Research Council, Old Blocks 9-10, University of Karachi, Karachi-75270 \\ ${ }^{2}$ Department of Zoology, ${ }^{3}$ Department of Botany, University of Karachi, Karachi-75270
}

\begin{abstract}
*Corresponding Author: Hinazafer, Vertebrate Pest Control Institute, Southern-zone Agricultural Research Centre, Pakistan Agricultural Research Council, Old Blocks 9-10, University of Karachi, Karachi-75270
\end{abstract}

\begin{abstract}
Laboratory studies were carried out to evaluate the repellency of essential oils of Azadirachtaindica (neem), Valerianaofficinalis(valerian), Acoruscalamus(sweet flag), Curcuma longa (turmeric) andSaussurealappa(costus)against red flour beetle, Triboliumcastaneum. Saussurealappa (costus) was found the best and the most persistent repellent among all the plants tested by achieving $88.67 \%$ repellency in first week which increased in second (88.79\%) and fourth week (88.92\%). Acoruscalamus (sweet flag) revealed $71.15 \%$ repellency at $0.100 \%$ in first week which decreased to $63.60 \%$ in second, $62.17 \%$ in fourth and $60.39 \%$ in eighth week. Azadirachtaindica (neem) showed $64.16 \%$ in first week which remain same in second but decreased to $58.87 \%$ in fourth and $45.72 \%$ in eighth week. Curcuma longa (turmeric) exhibited $60.45 \%$ repellency at $0.100 \%$ in first week which decreased to $49.02 \%$ in eighth week. At all other concentrations turmeric proved it a weak repellent by showing less than $40 \%$ repellency except at $0.050 \%$ in first week (42.75\%). Valerianaofficianalis(valerian) could not prove it a promising repellent.
\end{abstract}

Keywords: Triboliumcastaneum, Azadirachtaindica, Valerianaofficinalis, Acoruscalamus, Curcuma longa, Saussurealappa, repellency.

\section{INTRODUCTION}

Insect pests inflict heavy losses to stored grains during storage. Food and Agriculture Organization has reported 10- 25\% losses of the world's harvested food annually by insects and rodent pests (Anonymous, 1980). Chaudhry (1980) reported 2\% to 6\%overall lossesof stored grains and 3.24\% post-harvest loss of wheat in Pakistan every year by insect pests.Ahmad (1983) evaluated $2.5 \%$ postharvest losses of stored food commodities. Similarly Baloch et al. (1994) estimated 4\% storage losses to wheat in public sector. Red flour beetle (Triboliumcastaneum) is a major stored grain pest causing enormous losses to grain and grain products. Conventional pesticide pose detrimental effects on environment, other animals and human (Pitasawatet al., 2003). To avoid such hazards various plants are being explored against insect's pests. There is a need for development of effective, safe, environment friendly, convenient and inexpensive methods for protection of the stored grains. The trend for use of botanical insecticides throughout the world has led to conduct this research on plant oils against the red flour beetle. Higher plants contain a wide spectrum of secondary metabolites such as phenols, flavonoids, quinones, tannins, essential oils, alkaloids, saponins and sterols. Such plantderived chemicals are biodegradable and do not leave toxic residues or by-products. Essential oils have been screened for their medicinal and pesticide activities but detailed studies on their repellence have not been done. Therefore, there is an urgent need to discover the potential of different essential oils for control of post-harvest bio-deterioration of food commodities and thereby enhancing their shelf lives. Researchers have discovered many biological functions such as, attractants (pigments and scents), deterrents (repellents and antifeedents) or Insect growth regulators from plants (El-nahal, 1989;Deshmukh\&Renapurkar, 1987; Schmidt \&Risha,1989;Chander, 1990; Risha et.al, 1990; Su, 1991;Bhathal et.al, 1993;Rahman\& Schmidt, 1999; Sharma, 1992,Raguraman\& Singh, 1997; Khan et.al, 2000, Tariq \&Qadri, 2001;Kim et.al, 2003; Kostyukovsky et.al, 2005; Jillaniet.al, 2006; Jillaniet.al, 1988;Jilani\& Su,1983 ; Ullahet al. (1990); Ibrahim (1997) Liang et al. (2013); Liu et al. 
(2012);Seoet al. (2008);Khattaket al. (2009); Kumar et al. (2007);Spurr\& McGregor (2003) andNazliet al. (2003),

In this study, oils of five plants, namely,Azadirachtaindica (neem),Valerianaofficinalis (valerian), Acoruscalamus (sweet flag), Curcuma longa (turmeric)and Saussurealappa (costus) have been tested to evaluate their repellence against red flour beetle (Triboliumcastaneum).Thisstudy may be useful in utilization of indigenous plants for management ofred flour beetleand other insect pestsin stored wheat, flourand stored grains. Use of plant oils can be a better solution for safe, economical and environment friendly storage of the food grains. The findings of this study may be an addition for integrated pest management (IPM) models for the end-users.

\section{Materials ANd Methods}

\subsection{Rearing/ Culturing technique of Test Insects}

Insects were reared in laboratory at $30^{\circ} \mathrm{C} \pm 2^{\circ} \mathrm{C}$ temperature with a relative humidity of $60 \% \pm 5 \%$ on whole wheat grain as food medium contained in glass jars covered with muslin cloth. Ten days old adults of red flour beetle, Triboliumcastaneum (Herbst) (Coleoptra: Tenebrionidea) were used in the trials. To prepare insects of known age, sub-cultures of the insect from parental cultures were prepared by repeating raring/culturing procedure.

\subsection{Test Materials}

Five plants oils Azadirachtaindica (neem), Valerianaofficinalis (valerian), Acoruscalamus (sweet flag), Curcuma longa (turmeric) andSaussurealappa (costus) were tested to estimate their repellency. The plant oils were obtained by extracting plant powders with n-hexane on Soxhlet's extraction apparatus.

\subsection{Treatment Method for Repellency of the Plant Oils}

Repellence tests were conducted by following McDonald et.al (1970) and Jillani\& Su (1983).For the purpose, filter paper strips (What man No. 1, measuring, $10 \times 5 \mathrm{~cm}$ ) were treated separately with the plant oils with $0.100 \%, 0.050 \%$, and $0.025 \%$ concentrations. The treated filter paper strips were attached lengthwise, edge to edge to untreated filter paper strips of similar size with cellophane tape, after the evaporation of the solvent. On the center of the joined paper, a glass ring $(2.5 \mathrm{~cm}$ high with $7.0 \mathrm{~cm}$ internal diameter) was placed. Ten, 10-day old, laboratory reared Triboliumcastaneum starved for 24 hours were released in the middle of the test ring. After one hour and six hours, the settled insects were counted for five consecutive days. The repellency was observed continuously up to second, fourth and eighth week. Fresh insects were used in all tests, using the same treated filter paper arena. Percentage repellency was calculated by deducting the percentage of insects on the treated half from the insects on the untreated half divided by total number of insects, multiplied by hundred. Evaluation of weekly repellency of all the plant oils was carried out by comparing the results.

\section{RESUltS}

\subsection{Repellency of Neem Oil}

The maximum repellency, $49.20 \pm 1.50 \%$ was observed at $0.025 \%$ concentration which remain same in second week but increased up to $51.21 \pm 1.03 \%$ in fourth week. The repellency was decreased to $44.11 \pm 2.03 \%$ up to eighth week. The oil at $0.100 \%$ concentration triggered $64.16 \pm 1.10 \%$ repellency which remain same during the second week after that declined a little bit to $58.87 \pm 2.06 \%$ in fourth week and finally to $45.72 \pm 2.21 \%$ in eighth week of the study (table 1). Two way ANOVA was applied to know the repellency of plant oils against red flour beetle. The results were found highly significant for time (LSD $0.05=2.76)$ and concentration (LSD $0.05=2.39)$. The interaction of time and concentration was also found highly significant ( $<<0.001$, Appendix 1$)$.

\subsection{Repellency of Valerian Oil}

The minimum repellency was observed as much as $39.90 \pm 1.19 \%$ in first week at $0.025 \%$ which remain up to $31.56 \pm 1.49 \%$ in second, $26.19 \pm 1.33 \%$ in fourth and $19.44 \pm 2.50 \%$ in eighth week of the trials. Maximum repellency was observed as much as $48.29 \pm 2.36 \%$ in first week, $37.41 \pm 1.89 \%$ in second, $31.36 \pm 2.05 \%$ in fourth and again $37.56 \pm 1.37 \%$ in fourth week of the study (table 2). Repellency of the plant was found highly significant $(\mathrm{p}<0.001)$ for the time period (LSD $0.05=2.10$ ) whereas concentration was found non-significant ( $p>0.05$, LSD $0.05=2.59)$. However the interaction of time period and concentration was highly significant ( $\mathrm{p}<0.001$, Appendix 1). 


\subsection{Repellency of Sweet Flag Oil}

Repellency of sweet flag was $61.23 \pm 2.20 \%$ in first week which decline up to $52.08 \pm 2.39 \%$ in eighth week of the study at $0.025 \%$ concentration. At $0.100 \%$ concentration the repellency was $71.15 \pm 3.61 \%$ which decline up to $60.39 \pm 2.03 \%$ (table 3 ). Repellency was found significant $(p<0.05)$ for time period (LSD $0.05=5.23)$, whereas highly significant $(\mathrm{p}<0.001)$ for concentration $($ LSD $0.05=4.55)$. However the interaction of time and concentration was found non-significant (Appendix 1).

\subsection{Repellency of Turmeric Oil}

Turmeric oil showed $38.64 \pm 3.77 \%$ repellency in first week which decreased up to $39.33 \pm 1.99 \%$ in fourth week at $0.025 \%$ concentration. Maximum repellency, $60.45 \pm 1.45 \%$ was observed at $0.100 \%$ concentration in first week which remain $60.41 \pm 1.46 \%$ in second and $60.43 \pm 1.45 \%$ in fourth week. After which it declined up to $49.02 \pm 2.08 \%$ in eighth week (table4). The oil was found highly significant $(\mathrm{p}<0.001)$ for time period (LSD $0.05=3.97)$ and concentration (LSD $0.05=3.44)$, but the interaction of time and concentration was nonsignificant ( $p>0.05$, Appendix 1).

\subsection{Repellency of Costus Oil}

Costus oil showed highest $88.15 \pm 0.10 \%$ repellency at $0.100 \%$ concentration in first week which increased up to $88.79 \pm 0.96 \%$ in second week and up to $88.92 \pm 1.96 \%$ in fourth week. The repellency decreased to $83.56 \pm 2.51 \%$ only during eighth week of the study. At the lowest concentration $(0.025 \%)$ the repellency was found $71.59 \pm 3.07 \%$ in first week, $71.81 \pm 2.24 \%$ in second, $68.99 \pm 1.02 \%$ in fourth and $67.16 \pm 1.17 \%$ in eighth week of the study (Table 5). Findings were highly significant $(\mathrm{p}<0.001)$ for time period (LSD $0.05=3.31$ ) and concentration (LSD $0.05=2.87)$. The interaction among time and concentration was nonsignificant ( $\mathrm{p}>0.05$, Appendix 1).

\section{DISCUSSION}

Repellents are materials that offer some vapors which discourage the insects. Plants Oils, twigs hangings and their smoke omitted by burning is a common practice in villages for repellence against insect pests. Conventional pesticide pose detrimental effects on environment, other animals and human (Pitasawatet al., 2003). To avoid such hazards various plants are being explored against insects pests. Keeping the magnitude of insect pest problem in grain storage this study was designed to utilize some indigenous plants besides the well documented neem plant. For the purpose all the five plants (neem, valerian, sweet flag, turmeric and costus) were tested for their repellency against $\mathrm{T}$. castaneum. Plant materials gave very promising results for repellency (both in filter paper and mixing of extract/powder in medium) (Tables 63 to 77). Most of the plant materials proved them as promising repellents (above $40 \%$ repellency is considered as promising).

All plant oils proved them as promising repellents (above $40 \%$ repellency is considered as promising). The results are depicted in tables 1-5 whereas the plant oils significance as repellant is shown in appendix 1 . Among different concentrations, $0.100 \%$ was the most effective for all the plant oils generally.Neem oil showed $49.20 \pm 1.50 \%$ repellency at $0.025 \%$ concentration in first week of the study which remain same in second week then increased up to $51.21 \pm 1.03 \%$ in fourth week. After that the neem oil repellency was decreased to $44.11 \pm 2.03 \%$ in eighth week. Satti\&Elamin (2012) reported that the efficacy of neem seed oil increased up to $92.5 \%$ on the third week of experience which is in agreement with the present trials on neem oil for its repellence against red flour beetle. The oil at $0.100 \%$ concentration triggered $64.16 \pm 1.10 \%$ repellency which remain same during the second week after that declined a little bit to $58.87 \pm 2.06 \%$ in fourth and finally to $45.72 \pm 2.21 \%$ in eighth week of the study. Repellent effect was inconstant according to the dose like this study. The time factor (weeks) as well as concentration proved highly significant for time whereas their interaction was also found highly significant. Valerian oil revealed $39.90 \pm 1.19 \%$ repellency in first week at $0.025 \%$ which remain up to $31.56 \pm 1.49 \%$ in second, $26.19 \pm 1.33 \%$ in fourth and $19.44 \pm 2.50 \%$ in eighth week of the trials. Maximum repellency was observed as much as $48.29 \pm 2.36 \%$ in first week, $37.41 \pm 1.89 \%$ in second, $31.36 \pm 2.05 \%$ in fourth and again enhanced as $37.56 \pm 1.37 \%$ in eighth week of the study. Time period was found very significant whereas concentration was non-significant for the repellence activity of the plant; however the interaction of time period and concentration was highly significant. Sweet flag oil showed $61.23 \pm 2.20 \%$ repellence in first week which decline to $52.08 \pm 2.39 \%$ in eighth week of the study at $0.025 \%$ concentration. At $0.100 \%$ concentration the repellency was $71.15 \pm 3.61 \%$ which decline to $60.39 \pm 2.03 \%$. For sweet flag time period and concentration were found significant. However their interaction found non-significant. Turmeric oil showed $38.64 \pm 3.77 \%$ repellency in first week which decreased to $39.33 \pm 1.99 \%$ in fourth week at $0.025 \%$ concentration. Maximum 
repellency, $60.45 \pm 1.45 \%$ was observed at $0.100 \%$ concentration in first week which remain $60.41 \pm 1.46 \%$ in second and $60.43 \pm 1.45 \%$ in fourth week. After which it declined to $49.02 \pm 2.08 \%$ in eighth week. Time period and concentration were found highly significant but their interaction was nonsignificant. Like these studies Jilani\&Saxena, (1990) observed promising repellent activity of oils of turmeric, Curcuma longa (L.), sweet flag, Acoruscalamus (L.), neem, Azadirachtaindica and Margosan-O (neem product) against the lesser grain borer, Rhyzoperthadominica (F.) for eight weeks.

Costus oil proved the best by showing highest $88.15 \pm 0.10 \%$ repellency at $0.100 \%$ concentration in first week which increased up to $88.79 \pm 0.96 \%$ in second week and up to $88.92 \pm 1.96 \%$ in fourth week. The repellency decreased only to $83.56 \pm 2.51 \%$ during eighth week of the study. At the lowest concentration $(0.025 \%)$ the repellency was found $71.59 \pm 3.07 \%$ in first week, $71.81 \pm 2.24 \%$ in second, $68.99 \pm 1.02 \%$ in fourth and $67.16 \pm 1.17 \%$ in eighth week of the study. Findings were highly significant for the repellence activity of the plant. Time period and concentration were significant for the repellence activities however their interaction was nonsignificant. Like the present studies Kanvilet al. (2006) assessed repellency of V. officianalis, P. harmala, S. lappaand A. indicaoils against T. castaneum and discovered that V. officianalis most effective by showing maximum $(80.83 \%)$ repellency all through the first week at $1000 \mu \mathrm{g} / \mathrm{cm} 2$. Their findings are in disagreement with the results of this study in which S. lappashowed maximum $88.15 \pm 0.10 \%$ repellency at $0.100 \%$ concentration in first week which increased up to $88.79 \pm 0.96 \%$ in second week and up to $88.92 \pm 1.96 \%$ in fourth week; however they quoted $58.83 \%$ repellency imposed by A. indica oil which is in agreement with this study in which neem oil showed $51.21 \%$ repellency in first week on $0.050 \%$ concentration. Offered amount of $1,000 \mu \mathrm{g} / \mathrm{cm} 2$ was the most successful followed by 500 and 250 $\mu \mathrm{g} / \mathrm{cm} 2$. Petroleum ether extract of V. officianalis comprised $49.25 \%$ and $42.25 \%$ at 1,000 and 500 $\mu \mathrm{g} / \mathrm{cm} 2$ and $\mathrm{S}$. lappa having $47.75 \%$ average repellency were capable repellents against $\mathrm{T}$. castaneumadults over eight weeks' time, respectively, as against $56.63 \%$ in A. indica oil. In these studies costus, sweet flag and neem oils gave very promising results for repellency. This study maycontribute in to the use of non-hazardous, economic and environment friendly promising plant oils as repellent against the stored grain pests.

Table1. Repellency of neem oil against Triboliumcastaneum in choice test arena

\begin{tabular}{|c|c|c|c|c|}
\hline \multirow{2}{*}{ Concentrations (\%) } & \multicolumn{4}{|c|}{ Mean (\%) Repellancy after treatment up to eight weeks } \\
\cline { 2 - 5 } & 1st Week & 2nd Week & 4th Week & 8th Week \\
\hline 0.025 & $49.20 \pm 1.56$ & $51.21 \pm 1.03$ & $51.22 \pm 2.37$ & $44.11 \pm 2.05$ \\
\hline 0.050 & $60.76 \pm 1.13$ & $63.22 \pm 1.45$ & $58.42 \pm 1.53$ & $59.81 \pm 1.60$ \\
\hline 0.100 & $64.16 \pm 1.53$ & $64.16 \pm 1.10$ & $58.87 \pm 2.06$ & $45.72 \pm 2.21$ \\
\hline LSD*0.05 & Time & 2.76 & \\
\hline & Concentrations & 2.39 & \\
\hline
\end{tabular}

Table2. Repellency of valerian oil to Triboliumcastaneum in choice test arena

\begin{tabular}{|c|c|c|c|c|}
\hline \multirow{2}{*}{ Concentrations (\%) } & \multicolumn{4}{|c|}{ Mean (\%) Repellancy after treatment up to eight weeks } \\
\cline { 2 - 5 } & 1st Week & 2nd Week & 4th Week & 8th Week \\
\hline 0.025 & $39.90 \pm 1.19$ & $31.56 \pm 1.49$ & $26.19 \pm 1.33$ & $19.44 \pm 2.50$ \\
\hline 0.050 & $46.59 \pm 2.49$ & $39.50 \pm 1.34$ & $32.63 \pm 1.88$ & $17.95 \pm 1.21$ \\
\hline 0.100 & $48.29 \pm 2.36$ & $37.41 \pm 1.89$ & $31.36 \pm 2.05$ & $37.56 \pm 1.37$ \\
\hline LSD*0.05 & Time & 2.10 & \\
\hline \multicolumn{7}{|r}{} & Concentrations & 2.59 & \\
\hline
\end{tabular}

Table3. Repellency of sweet flag oil to Triboliumcastaneum in choice test arena

\begin{tabular}{|c|c|c|c|c|}
\hline Concentrations (\%) & \multicolumn{4}{|c|}{ Mean (\%) Repellancy after treatment up to eight weeks } \\
\cline { 2 - 5 } & 1st Week & 2nd Week & 4th Week & 8th Week \\
\hline 0.025 & $61.23 \pm 2.20$ & $58.76 \pm 3.08$ & $54.62 \pm 1.99$ & $52.08 \pm 2.39$ \\
\hline 0.050 & $63.89 \pm 3.36$ & $65.46 \pm 3.49$ & $66.94 \pm 4.84$ & $60.50 \pm 4.43$ \\
\hline 0.100 & $71.15 \pm 3.61$ & $63.60 \pm 2.03$ & $62.17 \pm 3.07$ & $60.39 \pm 2.03$ \\
\hline LSD*0.05 & Time & 5.23 & \\
\hline \multicolumn{7}{|r}{} & Concentrations & 4.55 & \\
\hline
\end{tabular}


Repellency of Five Indigenous Plant oils against Red Flour Beetle, Triboliumcastaneum

Table4. Repellency of turmeric oil against Triboliumcastaneum in choice test arena

\begin{tabular}{|c|c|c|c|c|}
\hline \multirow{2}{*}{ Concentrations (\%) } & \multicolumn{4}{|c|}{ Mean (\%) Repellancy after treatment up to eight weeks } \\
\cline { 2 - 5 } & 1st Week & 2nd Week & 4th Week & 8th Week \\
\hline 0.025 & $38.64 \pm 3.77$ & $42.55 \pm 1.89$ & $38.78 \pm 3.67$ & $39.33 \pm 1.99$ \\
\hline 0.050 & $42.75 \pm 1.96$ & $38.04 \pm 3.63$ & $39.33 \pm 2.34$ & $31.36 \pm 1.33$ \\
\hline 0.100 & $60.45 \pm 1.45$ & $60.41 \pm 1.46$ & $60.43 \pm 1.45$ & $49.02 \pm 2.08$ \\
\hline LSD $^{*} 0.05$ & Time & 3.97 & \\
\hline \multicolumn{7}{|r}{} & Concentrations & 3.44 & \\
\hline
\end{tabular}

Table5. Repellency of costus oil against Triboliumcastaneumin choice test arena

\begin{tabular}{|c|c|c|c|c|}
\hline $\begin{array}{c}\text { Concentrations } \\
(\%)\end{array}$ & \multicolumn{3}{|c|}{ Mean (\%) Repellancy after treatment upto eight weeks } \\
\cline { 2 - 5 } & 1st Week & 2nd Week & 4th Week & 8th Week \\
\hline 0.025 & $71.59 \pm 3.07$ & $71.81 \pm 2.24$ & $68.99 \pm 1.02$ & $67.16 \pm 1.17$ \\
\hline 0.050 & $82.67 \pm 2.46$ & $76.87 \pm 2.71$ & $76.06 \pm 2.27$ & $70.98 \pm 1.86$ \\
\hline 0.100 & $88.15 \pm 0.10$ & $88.79 \pm 0.96$ & $88.92 \pm 1.26$ & $83.56 \pm 2.51$ \\
\hline LSD $* .05$ & & Time & 3.31 & \\
\hline \multicolumn{7}{|r}{} & Concentrations & 2.87 & \\
\hline
\end{tabular}

All values are mean of five replicates \pm Standard Error, *Fisher's Least Significant Difference

Percent repellency $=(\mathrm{Nc}-\mathrm{Nt}) \times 100 / \mathrm{NT}$

Where,

$\mathrm{Nc}=$ Number of insects found in untreated arena

$\mathrm{Nt}=$ Number of insects found in treated arena

NT $=$ Total number of insects in untreated arena

Appendix1. Two-way ANOVA for repellency of the plant oils against Triboliumcastaneum

\begin{tabular}{|c|c|c|c|c|c|c|}
\hline Source & $\begin{array}{c}\text { Dependent } \\
\text { Variable }\end{array}$ & $\begin{array}{l}\text { Type III Sum of } \\
\text { Squares }\end{array}$ & df & $\begin{array}{r}\text { Mean } \\
\text { Square }\end{array}$ & $\mathbf{F}$ & Sig. \\
\hline \multirow[t]{5}{*}{ Time } & Neem & 811.5544133 & 3 & 270.5181378 & 19.21990792 & $2.51629 \mathrm{E}-08$ \\
\hline & Valerian & 3312.245112 & 3 & 1104.081704 & 66.46762528 & $4.09797 \mathrm{E}-17$ \\
\hline & Sweetflag & 468.60726 & 3 & 156.20242 & 3.089144007 & 0.035755556 \\
\hline & Turmaric & 547.8919383 & 3 & 182.6306461 & 6.253357536 & 0.001136982 \\
\hline & Costus & 390.0303517 & 3 & 130.0101172 & 6.40598344 & 0.000972296 \\
\hline \multirow[t]{5}{*}{$\begin{array}{c}\text { Concentrat } \\
\text { ion } \\
\end{array}$} & Neem & 1511.250893 & 2 & 755.6254467 & 53.68605456 & $5.71263 \mathrm{E}-13$ \\
\hline & Valerian & 51.50082333 & 2 & 25.75041167 & 1.550219252 & 0.222637671 \\
\hline & Sweetflag & 768.87661 & 2 & 384.438305 & 7.602860993 & 0.001354055 \\
\hline & Turmaric & 4714.266413 & 2 & 2357.133207 & 80.7093279 & $4.41999 \mathrm{E}-16$ \\
\hline & Costus & 3104.231543 & 2 & 1552.115772 & 76.47733994 & $1.18969 \mathrm{E}-15$ \\
\hline \multirow[t]{5}{*}{$\begin{array}{c}\text { Time * } \\
\text { Concentrat } \\
\text { ion } \\
\end{array}$} & Neem & 555.3003867 & 6 & 92.55006444 & 6.575543255 & 4.07192E-05 \\
\hline & Valerian & 1622.602443 & 6 & 270.4337406 & 16.28057821 & $4.07103 \mathrm{E}-10$ \\
\hline & Sweetflag & 234.04087 & 6 & 39.00681167 & 0.771419921 & 0.596172791 \\
\hline & Turmaric & 332.8053867 & 6 & 55.46756444 & 1.899234983 & 0.100245151 \\
\hline & Costus & 125.7534033 & 6 & 20.95890056 & 1.03270709 & 0.415966776 \\
\hline \multirow[t]{5}{*}{ Error } & Neem & 675.59484 & 48 & 14.0748925 & & \\
\hline & Valerian & 797.31932 & 48 & 16.61081917 & & \\
\hline & Sweetflag & 2427.11772 & 48 & 50.5649525 & & \\
\hline & Turmaric & 1401.85028 & 48 & 29.20521417 & & \\
\hline & Costus & 974.16512 & 48 & 20.29510667 & & \\
\hline \multirow[t]{5}{*}{ Total } & Neem & 191087.0232 & 60 & & & \\
\hline & Valerian & 75273.6085 & 60 & & & \\
\hline & Sweetflag & 232556.4398 & 60 & & & \\
\hline & Turmaric & 128976.9875 & 60 & & & \\
\hline & Costus & 369280.1463 & 60 & & & \\
\hline
\end{tabular}




\section{REFERENCES}

[1] Ahmad, H. 1983. Losses incurred in stored food grains by insect pests: A review. Pak. J. Agric. Res., 4(3): 198-207.

[2] Anonymous 1980.Introduction to Detia fumigation. Fumigation Detia export GmH: 3.

[3] Baloch, U. K., Irshad, M. and Ahmad, M. 1994.Loss assessment and loss prevention in wheat and storagetechnology development and transfer in Pakistan. Proc. Int. Working Conf. Stored Prod. Prot., Vol. 2: 902-905.

[4] Bhathal, S. S., Singh, D., Singh, S. and Dhillon, R. S. 1993. Effect of crude root oils of Inularacemosa and Saussurealappa on feeding, survival and development of Spodopteralitura (Lepidoptera: Noctuidae) larvae. Euro. J. Entomol. 90: 239-40.

[5] Chander, H., Kulkarni, S. J. and Berry, S. K. 1990.Acoruscalamus(Rhizomes) as a protectant of milled rice against Sitophilusoryzae and Triboliumcastaneum.J. Fd. Sci. Technol. 27:171-174.

[6] Chaudhry, M.A. 1980. Aggregate post-harvest food grain losses in Pakistan.Report (4).Dept. Agri. Market. Uni. Agri. Faisalabad.

[7] Deshmukh, P. B. and Renapurkar, D. M. 1987. Insect growth regulatory activity of some indigenous plant extracts. Insect Sci. Appli. 8: 81-83.

[8] El-nahal, A. K. M., Schmidt, G. H. and Risha, E. M. 1989.Vapours of Acoruscalamus oil: A space treatment for stored-product insects. J. Stored Prod.Res. 25: 211-6.

[9] Ibrahim, F. (1997).Studies on turmeric Curcuma longa as protectant against insect pests of stored rice. $\mathrm{Ph}$. D. thesis, University of Karachi, Karachi, Pakistan.

[10] Jilani, G. and Saxena, R. C. (1990). Repellent and feeding deterrent effects of turmeric oil, sweet flag oil, neem oil and a neem-based insecticide against lesser grain borer (Coleoptera: Bostrychidae). Journal of Economic Entomology, 83 (2): 629-634.

[11] Jilani, G. and Su, H. C. F. (1983). Laboratory studies on several plant materials as insect repellent for protection of cereal grains. J. Econ. Entomol, 76 (1): 154-157.

[12] Jilani, G. and Su, H.C.F. 1983. Laboratory studies on several plant materials as insect repellent for protection of cereal grains. J. Econ. Entomol, 76(1): 154-157.

[13] Jilani, G., Khattak, M. K. and Shahzad, F. 2006. Toxic and growth regulating effect of ethanol extract and petroleum ether extract of Valarianaofficianalis L. against BactrocerazonataSaunder. Pak. Entomol. 28(1): 10-14.

[14] Jilani, G., Saxena, R. C. and Rueda, B. P. 1988. Repellent and growth-inhibiting effects of turmeric oil, sweetflag oil, neem oil and Margosan-O on red flour beetle (Coleoptera: Tenebrionidae). J. Econ. Entomol. 81(4): 1226-1230.

[15] Khan, M. F., Khan, M. A. and Tabassum, R. 2000. Lethal effects of neem fruit extracts against mosquitoes as compared to killi fish. Pakistan J. Biol. Sci. 3(6): 1037-1038.

[16] Khattak, M. K., Shahazad, M. F. and Jilani, G. (2006).Effect of different extracts of harmal (Peganumharmala L.), rhizomes of kuth (Saussurealappa C. B. Clarke) and balchar (Valarianaofficianalis L.) on the settling and growth of peach fruit fly (Bactrocerazonata Saunders).Pakistan Entomologist, 28: 15-19.

[17] Kim, S. I., Park, C., Ohh, M. H., Cho, H. C. and Ahn, Y. J. 2003. Contact and fumigant activities of aromatic plant extracts and essential oils against Lasiodermaserricorne(Coleoptera:Anobiidae). J. Stored Prod. Res. 39(1):11-19.

[18] Kostyukovsky, M., Shaaya, E. and Ravid, U. 2005.Essential oils for the control of stored product insect pests in dry food. Proc. Nat. Preser. Food Systems. March 30-31, Princeton, NJ.

[19] Kumar, P., Mishra, S., Malik, A. and Satya, S. (2011). Repellent, larvicidal and pupicidal properties of essential oils and their formulations against the housefly, Muscadomestica.Medical and Veterinary Entomology, 25 (3): 302-310.

[20] McDonald, L. L., Guy, R. H. and Speir, R. D. 1970. Preliminary evaluation of some new candidate materials as toxicant, repellents and attractants against stored product insects. I. USDA. Marketing Res. Report, 882 pp.

[21] Nazli, R., Jilani, G., Ibrahim, F., Kazmi, A. R. and Solangi, A. H. (2003). Repellency of neem seed oil obtained from different locations of Pakistan against red flour beetle. Pak. Entomol., 25 (2): 201-205.

[22] Pitasawat, B., Choochote, W., Tuetun, B., Tippawangkosol, P., Kanjanapothi1, D., Jitpakdi, A. and Riyong, D. (2003). Repellency of aromatic turmeric Curcuma aromatic under laboratory and field conditions.Journal of Vector Ecology, 28 (2): 234-240.

[23] Raguraman, S. and Singh, D. 1997.Biopotentials of Azadirachtaindicaand Cedrusdeodara oils on Callosobruchuschinensis. J. Pharma. 35: 344-348. 
[24] Rahman, M. M. and Schmidt, G. H. 1999.Effect of Acoruscalamus(L.) (Araceae) essential oil vapours from various origins on Callosobruchusphaseoli(Gyllenhal) (Coleoptera: Bruchidae). J. Stored Pro. Res. 35(3): 285- 295.

[25] Risha, E, El-Nahal, A. K. M. and Schmidt, G. H. 1990.Toxicity of vapours of Acoruscalamus(L.)oil to the immature stages of some stored-product Coleoptera. J. Stored Prod. Res. 26:133-137.

[26] Satti, A. A. and Elamin, M. M. (2012). Insecticidal activities of two meliaceous plants against TrogodermagranariumEverts (Coleoptera: Dermeidstae). I.J.S.N., 3 (3): 696-701.

[27] Schmidt, G. H. and Risha, E. M. 1989.Vapours of Acoruscalamus oil are suitable to protect stored products against insects. Proc. of Conf. 3: 977-997.

[28] Seo, S. M. and Park, K. (2012).Larvicidal activity of medicinal plant extracts and lignin identified in Phrymaleptostachya var. asiatica roots against housefly (Muscadomestica L.).Parasitology Research, 110 (5): 1849-1853.

[29] Sharma, G. K. 1992. Growth inhibitor activity of Azadirachtaindica on Corcyra cephalonica.Phytoparasitics. 20: 251-258.

[30] Spurr, E. B. and McGregor, P. G. (2003). Potential invertebrate antifeedants for toxic baits used for vertebrate pest control. Science for Conservation, 232: 36.

[31] Su, H.C.F. 1991. Laboratory evaluation of toxicity of calamusoil against four species of stored product insects.J. Entomol. Sci. 26(1): 76-80.

[32] Tariq, R. M. and Qadri, S. S. 2001. Repellent activity of some local plants oil, two commercial repellents, di-methyl phthalate and non-alcoholic against dengue vector mosquitoes. Pak. J. Entomol. 16(1-2): 7-10.

[33] Ullah, N., Jilani, G., Khan, M. I. and Ghiasuddin. (1990). Repellency of turmeric and its derivatives applied to rice against the red flour beetle, Triboliumcastaneum(Hbst.) (Coleoptera: Tenebrionidae). Pak. Entomol., 12 (1-2): 38-41.

Citation: Hinazafer, "Repellency of Five Indigenous Plant oils against Red Flour Beetle, Tribolium castaneum" International Journal of Research Studies in Zoology, vol. 6, no. 1, p. 5-11, 2020. DOI: http://dx.doi.org/ 10.20431/2454-941X.0601002.

Copyright: () 2020 Authors. This is an open-access article distributed under the terms of the Creative Commons Attribution License, which permits unrestricted use, distribution, and reproduction in any medium, provided the original author and source are credited. 